\title{
PERFORMANCE OF ALUMINIUM SULPHATE AND POLYALUMINIUM CHOLORIDE IN BIODIESEL WASTEWATER
}

\author{
N. Nasir ${ }^{1}$ and Z. Daud ${ }^{1}$ \\ ${ }^{1}$ Faculty of Civil and Environmental Engineering, Universiti Tun Hussein Onn \\ Malaysia, 86400 Parit Raja, Batu Pahat, Johor Malaysia \\ *Email: nazlizan85@gmail.com, zawawi@uthm.edu.my \\ Phone: +6074564223; Fax: +6074536588
}

\begin{abstract}
The production of biodiesel through the transesterification method produces a large amount of wastewater that contains a high level of chemical oxygen demand (COD) and oil and grease $(\mathrm{O} \& \mathrm{G})$. In this study, coagulation was adopted to treat the biodiesel wastewater. Two types of coagulation were examined using a standard jar test apparatus, i.e. polyaluminium chloride (PAC) and aluminium sulphate. The effects of $\mathrm{pH}$ and coagulant dosage were examined at $150 \mathrm{rpm}$ of rapid mixing and $20 \mathrm{rpm}$ slow mixing and 30 min settling time. Higher removal of suspended solids (SS), colour, oil and grease (over 90\%), and COD (over $80 \%$ ) were achieved at $\mathrm{pH}$ 6. PAC was found to be superior to aluminium sulphate, yielding a lower amount of coagulation, i.e., 300 $\mathrm{mg} / \mathrm{L}$. The result indicated that the coagulation and flocculation process played bigger roles in the integrated treatment system.
\end{abstract}

Keywords: Coagulation-flocculation; coagulation dosage, biodiesel wastewater

\section{INTRODUCTION}

Biodiesel has significant promise as a potential replacement for petroleum-based diesel fuel [1]. Biodiesel is an alternative diesel fuel produced from the transesterification reaction of triglycerides from vegetables oils or fats with alcohols like methanol and ethanol in the presence of a homogeneous base catalyst like $\mathrm{NaOH}$ or $\mathrm{KOH}$. Biodiesel is biodegradable, non-toxic, burns with a low sulphur, carbon monoxide, and aromaticfree emission profile, and is environmentally beneficial [2-7]. Although biodiesel generates low greenhouse gas emissions and has a very low toxicity, its production may cause some environmental problems. In the final process of biodiesel production, water is usually introduced into the biodiesel to remove impurities. This washing step is repeated 2-5 times, depending on the quantity of impurities in the methyl ester. A large amount of wastewater, 20-120 litres per 100 litres of biodiesel, is generated in this process [8-10]. Wastewater from the production processes is contaminated with waterinsoluble methyl ester, methanol and by the product itself. It also contains a significantly higher content of COD of $170,000 \mathrm{mg} / \mathrm{L}$ and oil and grease of $9,000 \mathrm{mg} / \mathrm{L}$ [11]. The main component of the wastewater is the residual remaining oil, so such wastewater should not be discharged into public drainage because the oil causes plugging of drains and decreases biological activity in sewage treatment. The wastewater is basic (alkaline), with a high content of oil and grease, and a low content of nitrogen and phosphorus. As such, biological treatment of the biodiesel wastewater is 
difficult because the composition of the biodiesel wastewater is not suitable for microbial growth [8]. According to Sawin, Taweepreda [1], wastewater from the biodiesel production process contains white muddy particles like milk that are caused by the oil emulsified in water. However, most of the previous works on biodiesel have mainly focused on the technical processes of the production, while its environmental management aspect has usually been neglected [11].

A previous study showed that the biological treatment of biodiesel wastewater is difficult because the composition of biodiesel is not suitable for microbial growth [8]. For this reason, supportive physico-chemical methods are often used. One of the most frequently employed methods is coagulation. Coagulation and flocculation are widely used in water and wastewater treatment. The coagulation process is effective for removing high concentration organic pollutants $[12,13]$, heavy metal and some anions. Coagulation is the process where compounds such as metals salts are added to effluents in order to destabilize colloid material. As a result, the aggregation of small particles into larger and more easily removed floc takes place. Particles destabilized by charge neutralization are called primary floc or coagulation flocs, while flocs enlarged by bridging are sometimes termed as secondary flocs [14]. The effectiveness of the process is influenced by the coagulating agent, the coagulant dosage, the $\mathrm{pH}$ and ionic strength, as well as the concentration and the organic compounds $[13,14]$. The objectives of this study were to simulate coagulation/flocculation process efficiency for a biodiesel wastewater treatment plant with respect to removal of SS, colour, COD and oil and grease using aluminium sulphate [15] and polyaluminium chloride (PAC). We also investigate the optimum coagulant $\mathrm{pH}$ and optimum coagulant dosages on the coagulation process, and compare the effectiveness between aluminium sulphate and polyaluminium chloride as coagulant in biodiesel wastewater treatment.

\section{EXPERIMENTAL SET-UP}

\section{Sample Collection and Material}

A sample of biodiesel wastewater was collected from UTHM Biodiesel Pilot Plant which is situated in University Tun Hussein Onn Malaysia. This plant uses palm oil as a feedstock and an alkali-catalyzed transesterification process. The characteristics of this biodiesel wastewater were analysed according to the standard methods for examination of water and wastewaters [16], as shown in Table 1. The sample was stored in a refrigerator in order to minimize changes in the characteristics of the wastewater, since it may vary from day to day. Two types of coagulants were considered, namely aluminium sulphate and polyaluminium chloride.

Table 1. Characteristics of biodiesel wastewater.

\begin{tabular}{lc}
\hline \multicolumn{1}{c}{ Parameters } & Value \\
\hline Suspended solids (SS) & $348 \mathrm{mg} / \mathrm{L}$ \\
COD & $15,500 \mathrm{mg} / \mathrm{L}$ \\
Colour & $88 \mathrm{PtCo}$ \\
Oil and grease & $2,700 \mathrm{mg} / \mathrm{L}$ \\
$\mathrm{pH}$ & $4.5-5.5$ \\
\hline
\end{tabular}




\section{Experimental Procedure}

Coagulation and flocculation studies were performed in standard jar-test apparatus, with Jar Tester Model CZ150 comprising 6 paddle motors (24.5 mm x $63.5 \mathrm{~mm}$ ), equipped with 6 beakers of 1 litre volume. Twelve beakers were positioned on a magnetic stirrer with the specified dosage of coagulant. The $\mathrm{pH}$ value of 1 litre of biodiesel wastewater sample was adjusted to $\mathrm{pH}$ values in the range $2-12$, by using $1.0 \mathrm{M} \mathrm{H}_{2} \mathrm{SO}_{4}$ or $1.0 \mathrm{M}$ $\mathrm{NaOH}$, after the addition of $100 \mathrm{mg} / \mathrm{L}$ alum or PAC to the sample. After rapid mixing for $4 \mathrm{~min}$ at $150 \mathrm{rpm}$ and slow mixing for $20 \mathrm{~min}$ at $20 \mathrm{rpm}$, the liquid was clarified for $30 \mathrm{~min}$, then the supernatant was withdrawn from a point located about $2 \mathrm{~cm}$ below the top of the liquid level of the beaker to determine the COD, SS, colour, and oil and grease $(O \& G)$ using the standard methods $[10]$ so that the effect of $\mathrm{pH}$ could be studied. $50,100,150,200,250,300,350,400,450,500,550$ and $600 \mathrm{mg} / \mathrm{L}$ alum or PAC was added to 1 litre of the biodiesel wastewater sample. After stirring and clarifying as described above, the supernatant was withdrawn to determine the COD, SS, colour and oil and grease, so that the effect of coagulant dosage could be studied.

\section{Analytical Analysis}

Analyses were undertaken in triplicate. The $\mathrm{pH}$ was measured by a $\mathrm{pH}$ meter (Cyberscan 20), while oil and grease were measured according to standard method 1164, EPA. Suspended solids, colour and COD were measured by a DR $5000 \mathrm{HACH}$ spectrophotometer, adapted from the Standard Method for Water and Wastewater. All water colour measures described in this work are report as true colour values using the platinum-cobalt (Pt-Co) method, the unit of colour being that produced by $1 \mathrm{mg}$ platinum/L in the form of the chloroplatinate ion [16]. The samples were filtered using $0.45 \mu \mathrm{m}$ filter paper before colours were measured.

\section{RESULTS AND DISCUSSION}

\section{Effect of pH on Coagulation}

The $\mathrm{pH}$ affects not only the surface charge of coagulants, but also the stabilization of the suspension; it is the most important variable in the coagulation process for water treatment $[17,18]$. A suitable $\mathrm{pH}$ will help to neutralize the negative charge of colloidal particles and to form linkages between colloid particles, thus effectively helping with floc formation and reaching the expected settlement [19].

Therefore, the study of $\mathrm{pH}$ was essential to determine the optimum $\mathrm{pH}$ condition for the treatment system. The effect of $\mathrm{pH}$ was analysed at $100 \mathrm{mg} / \mathrm{L}$ dosages, with a $150 \mathrm{rpm}$ mixing rate for 4 minutes and $20 \mathrm{rpm}$ mixing rate for 20 minutes, plus 30 minutes of settling time for a $\mathrm{pH}$ range from 2 to 12 . The efficiencies based on the removal and reduction of SS, colour, COD and oil and grease in the biodiesel wastewater were used to determine the optimum $\mathrm{pH}$. 


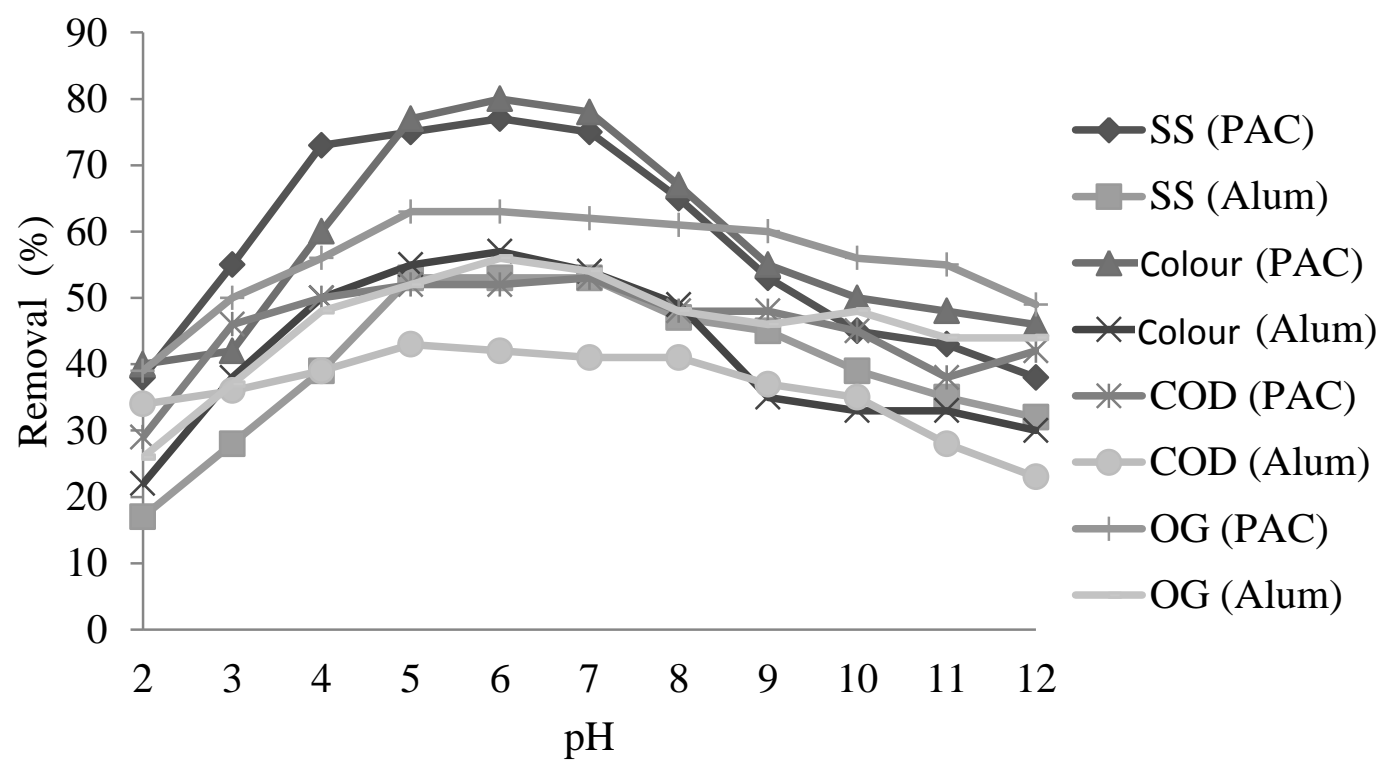

Figure 1. Percentage of SS, colour, COD and oil and grease removal against $\mathrm{pH}$ using $100 \mathrm{mg} / \mathrm{L} \mathrm{PAC}$ and alum.

Figure 1 presents the results of the effect of $\mathrm{pH}$ on SS, colour, COD and oil and grease removal by using alum and PAC as coagulant. The figure shows that the optimum $\mathrm{pH}$ for both coagulants is in the range 5 to 8 . PAC gives a greater range of $\mathrm{pH}$ and better removal percentage compared to alum due its solubility and elements of higher ions in the PAC $[13,20]$. At lower $\mathrm{pH}$, most of the organic substance has no charge or is neutral at its surface, while hydrolysis salts such as PAC and alum have a lot of positive charge in their hydrolysis chains [19]. According to Figure 1, pH 6 shows the highest percentage removal of SS, colour, COD and oil and grease for both alum and PAC. The percentages of removal of SS, colour, COD and oil and grease for alum are $53 \%, 57 \%, 42 \%$ and $56 \%$, while for PAC the highest removal percentages of SS, colour, COD and oil and grease are $77 \%, 80 \%, 62 \%$ and $63 \%$ respectively. The study shows that $\mathrm{pH}$ control affected the concentration of polyaluminium chloride and alum used [21]. The efficiency of grease and oil removal using both coagulants at $\mathrm{pH}$ values of 6-7 was greater than $90 \%$. A decrease in the removal efficiency of polyaluminium chloride occurred when the $\mathrm{pH}$ tended towards acidic or basic values and this is in accordance with the amphoteric character of aluminium hydroxide, which precipitates at $\mathrm{pH}$ 6-7, while its solubility increases as the solution becomes either more acidic or alkaline $[13,19,22]$. The $\mathrm{pH}$ of biodiesel wastewater is found to have a tremendous effect on SS, colour, COD and oil and grease removal through the coagulation process.

\section{Effect of Coagulant Dose on Coagulation}

Dosage was the most important parameter that was considered to determine the optimum condition for the performance of coagulation and flocculation. Each type of coagulant has its own characteristic optimum dosage range. Basically, insufficient dosage or overdosing will result in poor performance in flocculation $[17,18]$. Therefore, it was crucial to determine the optimum dosage in order to minimize the dosing cost and 
obtain the optimum performance in treatment. The effect of dosage was analysed at a $150 \mathrm{rpm}$ mixing rate for 4 minutes and $20 \mathrm{rpm}$ mixing rate for 20 minutes, followed by 30 minutes of settling time for a dosage range which varied from $50 \mathrm{mg} / \mathrm{L}$ to $600 \mathrm{mg} / \mathrm{L}$.

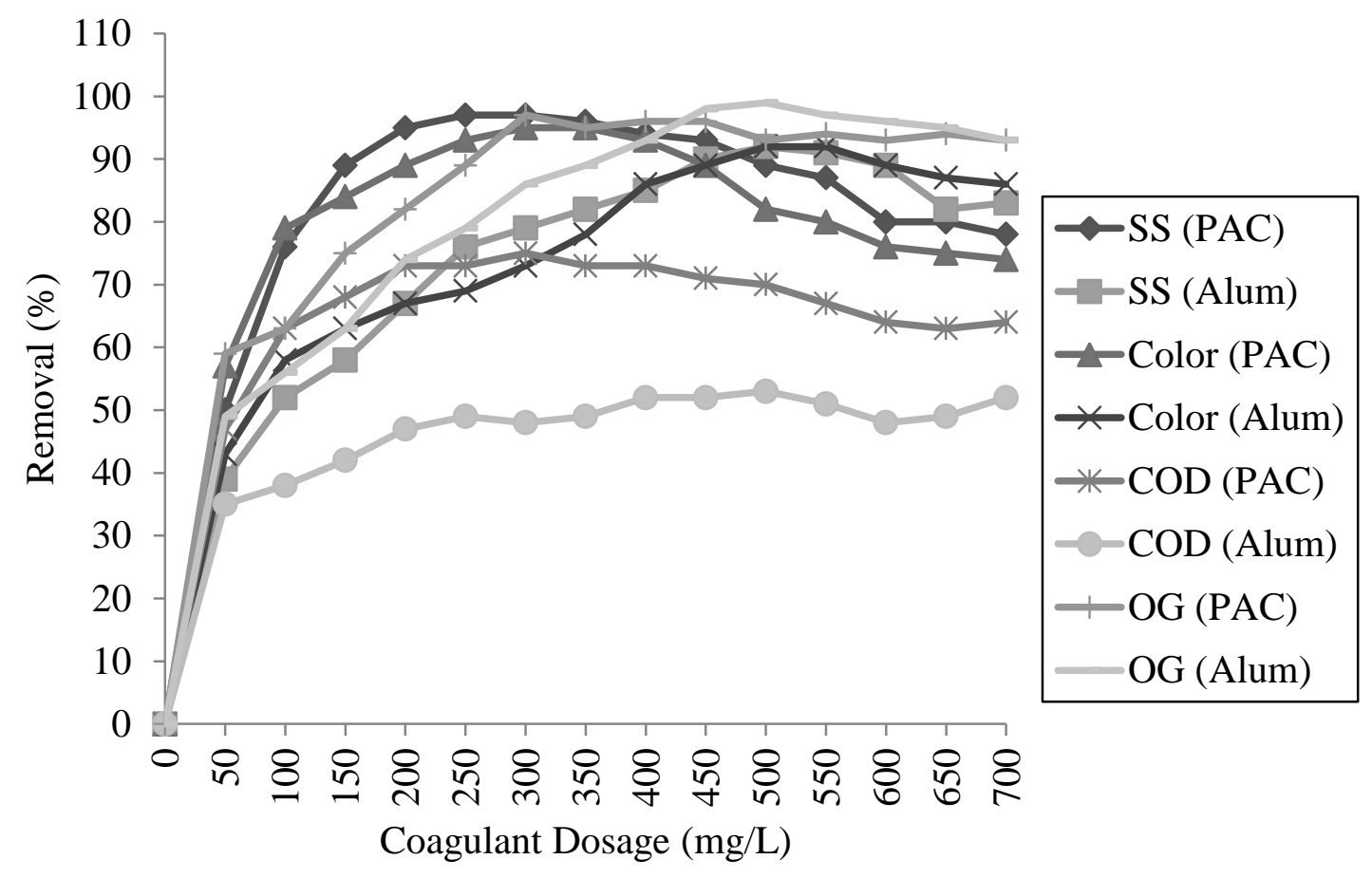

Figure 2. Percentage SS, colour, COD and oil and grease removal against PAC and alum dosage at $\mathrm{pH} 6$.

The effect of dosage coagulants on SS, colour, COD and oil and grease are shown in Figure 2. It is clearly shown that PAC removed SS, colour, COD and oil and grease the best at $97 \%, 95 \%, 81 \%$ and $97 \%$ with $300 \mathrm{mg} / \mathrm{L}$, while alum removal of SS, colour, COD and oil and grease was the highest at 92\%, 92\%, 53\% and 99\% with 500 $\mathrm{mg} / \mathrm{L}$. COD removal efficiency decreased with increasing coagulant concentration. At high coagulant doses, metal hydroxides are produced and organic substances are removed by incorporation into sorption onto hydroxide flocs [12, 13]. When the concentrations were higher than necessary, the efficiency of COD removal decreased because the flocs formed by coagulation were smaller and less compact, which was not favourable for sludge [18]. The findings show the comparison of oil and grease removal between alum and PAC. For alum, the maximum removal of oil and grease increase stated decreased at a dosage of $550 \mathrm{mg} / \mathrm{L}$. The PAC's maximum reduction of oil and grease $(97 \%)$ which started at a dosage of $100 \mathrm{mg} / \mathrm{L}$, began to decrease at a dosage of $450 \mathrm{mg} / \mathrm{L}$. Rattanapan, Sawain [21] investigation of three coagulants, namely, alum, PAC and ferric chloride, for removing oil and grease in biodiesel wastewater found them to be equally effective. Hence, alum was found to provide the best removal compared to other coagulants. From the figures, all the residual parameters decreased while their removal efficiencies improved substantially as the dosage of aluminium sulphate or polyaluminium chloride increased until reaching the optimum dosage. When the dosage exceeded the optimum dosage for both coagulants, there was a decrease in the removal efficiency for all the parameters. Each type of coagulant has its own 
optimal dose range. A coagulant is a compound that helps coagulation, which helps destabilize the colloidal particles, so helping the formation of floc and consequently accelerating the settling process $[13,19,22]$.

\section{CONCLUSIONS}

The results showed that polyaluminium chloride (PAC) was more effective in biodiesel wastewater treatment compared to alum. However, alum achieved a higher percentage removal of oil and grease. The percentage of removal of suspended solids, colour, COD and oil and grease increased until the optimum value of $\mathrm{pH}$ or dosage was achieved, after which the percentage slowly decreased. The result showed that the optimum $\mathrm{pH}$ for both coagulants is 6 and the optimum coagulant doses of aluminium sulphate and polyaluminium chloride were $500 \mathrm{mg} / \mathrm{L}$, and $300 \mathrm{mg} / \mathrm{L}$ respectively. At optimum $\mathrm{pH}$, the percentages of SS, colour, COD and oil and grease removal by alum are $53 \%$, $57 \%, 42 \%$, and $56 \%$, while by PAC they are $77 \%, 80 \%, 62 \%$, and $63 \%$ respectively. At optimum coagulant dose, the percentages of SS, colour, COD and oil and grease removal by alum are $92 \%, 92 \%, 53 \%$, and 99\%, and by PAC are 97\%, 95\%, 81\%, and $97 \%$ respectively. The coagulation process and all the removal parameters were considerably affected by $\mathrm{pH}$, coagulant dosage, and the initial characteristics of the biodiesel wastewater for both alum and PAC. Investigating the influence of the rapid mixing parameters, the time and intensity of mixing, as well as slow mixing parameters on turbidity removal by alum and PAC is also suggested for future studies.

\section{ACKNOWLEDGEMENTS}

The authors would like to thank the Ministry of Higher Education Malaysia and University Tun Hussein Onn Malaysia (UTHM) for financially supporting this study.

\section{REFERENCES}

[1] Sawin A, Taweepreda W, Puetpaiboon U, Suksaroj C. Destabilization and demulsification of wastewater from biodiesel production by aluminum salts. Thai Journal of Environmental Engineering. 2010;24:57-66.

[2] Ma F, Hanna MA. Biodiesel production: a review. Bioresource Technology. 1999;70:1-15.

[3] Abbaszadeh A, Ghobadian B, Najafi G, Yusaf T. An experimental investigation of the effective parameters on wet washing of biodiesel purification. International Journal of Automotive and Mechanical Engineering. 2014;9:152537.

[4] Soon LB, M. Rus AZ, Hasan S. Continuous biodiesel production using ultrasound clamp on tubular reactor. International Journal of Automotive and Mechanical Engineering. 2013;8:1396-405.

[5] Ghobadian B, Najafi G, Nayebi M. A semi-empirical model to predict diesel engine combustion parameters. Journal of Mechanical Engineering and Sciences. 2013;4:373-82.

[6] Mat Yasin MH, Mamat R, Sharma KV, Yusop AF. Influence of palm methyl ester (PME) as an alternative fuel in multicylinder diesel engine. Journal of Mechanical Engineering and Sciences. 2012;3:331-9. 
[7] Rahim R, Mamat R, Taib MY, Abdullah AA. Influence of fuel temperature on a diesel engine performance operating with biodiesel blended. Journal of Mechanical Engineering and Sciences. 2012;2:226-36.

[8] Suehara K-i, Kawamoto Y, Fujii E, Kohda J, Nakano Y, Yano T. Biological treatment of wastewater discharged from biodiesel fuel production plant with alkali-catalyzed transesterification. Journal of Bioscience and Bioengineering. 2005;100:437-42.

[9] Marchetti JM, Miguel VU, Errazu AF. Possible methods for biodiesel production. Renewable and Sustainable Energy Reviews. 2007;11:1300-11.

[10] Phukingngam D, Dararat S, Cavalparit O. Study of Biogas Production Potential of Biodiesel Wastewater. Proceedings of the 7th National Environment Conference, Environmental Engineering Association of Thailand. Bangkok2008.

[11] Srirangsan A, Chavalparit O. Treatment of biodiesel wastewater by electrocoagulation process. Actas de Proceedings of the International Symposium on Environmental Management: Hazardous-Environmental Management Toward Sustainability2009. p. 26-7.

[12] Wang Z-P, Zhang Z, Lin Y-J, Deng N-S, Tao T, Zhuo K. Landfill leachate treatment by a coagulation-photooxidation process. Journal of Hazardous Materials. 2002;95:153-9.

[13] Lee MR, Daud Z, Abdul Latif AA. Treatment of leachate by CoagulationFlocculation using different coagulants and polymer. International Journal on Advanced Science, Engineering and Information Technology. 2012;2:1-4.

[14] Stephenson RJ, Duff SJB. Coagulation and precipitation of a mechanical pulping effluent-I. Removal of carbon, colour and turbidity. Water Research. 1996;30:781-92.

[15] Palumbo G, Amante F, Andrea Ugo A. Drive away quality - testing procedure for manual transmission based upon experimental analysis of customer driving. Engine Expo. Turin: Fiat Group; May 2007.

[16] Rice EW, Association APH. Standard methods for the examination of water and wastewater: American Public Health Association Washington, DC; 2012.

[17] American Water Works Association. Water Quality and Treatment: A Handbook of Community Water Supplies. 5 ed: McGraw-Hill, Inc.; 1999.

[18] Hassan A, Ariffin M, Tan PL, Noor ZZ. Coagulation and flocculation treatment of wastewater in textile industry using chitosan. Journal of Chemical and Natural Resources Engineering. 2009;4:43-53.

[19] Gupta BS, Hashim MA. Coagulation and flocculation. In Water Treatment Plants. New Delhi, India: Narosa Publisher; 1996.

[20] Pernitsky DJ, Edzwald JK. Selection of alum and polyaluminum coagulants: Principles and applications. Journal of Water Supply: Research and TechnologyAQUA. 2009;55:121-41.

[21] Rattanapan C, Sawain A, Suksaroj T, Suksaroj C. Enhanced efficiency of dissolved air flotation for biodiesel wastewater treatment by acidification and coagulation processes. Desalination. 2011;280:370-7.

[22] Rui LM, Daud Z, Latif AA. Treatment of Leachate by coagulation-flocculation using different coagulants and polymer: A review. International Journal on Advanced Science, Engineering and Information Technology. 2012;2:1-4. 